\title{
The Illinois Oil Fields
}

BY H. A, WHEELER, ST. LOUIS, MO.

(New York Meeting, February, 1914)

CONTENTS

History . . . . . . . . . . . . . . . . . . . . . 533

Location . . . . . . . . . . . . . . . . . . 536

Geology :. . . . . . . . . . . . . . . . . . . 539

Description of the Eastern Field . . . . . . . . . . . . . . . . . . . . . 543

Description of the Western Field . . . . . . . . . . . . . . . . . 546

Quality of the Oil . . . . . . . . . . . . . . . . 549

The Oil Sands . . . . . . . . . . . . . . . . . . . . . 549

Drilling Features" . . . . . . . . . . . . . . . . . . . . . 551

Well Density .... . . . . . . . . . . . . . . . . . . . . 552

Plant Equipment . . . . . . . . . . . . . . . . . . . 554

Market Features . . . . . . . . . . . . . . . . . . . . . . 555

Production Prices . . . . . . . . . . . . . . . . . . . . 557

Royalties and Rentals . . . . . . . . . . . . . . . . . . . 558

Cost of Oil Leases . . . . . . . . . . . . . . . . . . . . . . . . . . . . . . 558

Operating Expenses. . . . . . . . . . . . . . . . . . . . . . . . . . . 559

Operating Profits . .. . . . . . . . . . . . . . . . . . . . . . . 559

Gas Developments . . . . ... . . . . . . . . . . . . . . 560

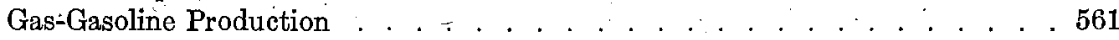

Statistics . . . . . . . . . . . . . . . . . . . 562

\section{History}

ILIINOIS has so recently attained the third place in the oil production of the United States that few realize its great importance, or are aware of its highly profitable character. Since 1907 Illinois has furnished about 15 per cent. of the United States output and about 10 per cent. of the world's production. The value of the output in 1913 is estimated at $\$ 30,000,000$, of which about $\$ 20,000,000$ is profit.

The present prosperity dates from 1905, but efforts have been made since 1865 to develop production and geologists have been very sanguine as to its future for over 25 years. Had the oil operators been as confident as the geologists, the field would have been opened at least 30 years earlier. For the rich Eastern Illinois oil field is located along the La Salle anticline, that was mapped 46 years ago by Professor. Worthen in the 
first geological survey of the State. ${ }^{1}$ Prof. T. B. Comstock enthusiastically wrote in $1887^{2}$ about the highly promising character of this anticline, to which he again called attention in $1889 .^{3}$

The writer's studies in 1888 were convincing as to its oil future, yet to have then advocated drilling would have earned the reputation of being a dreamer. In fact, as late as 1903 the writer's suggestion to a prominent Pittsburg oil operator to prospect in Illinois met with contempt and derision, which was representative of the general feeling then held by the oil fraternity, yet this same party made a large fortune four years later out of a block of Illinois oil leases.

The first commercial wells were brought in at Litchfield, 50 miles northeast of St. Louis, where in 1882, in drilling for coal, gas was discovered that supplied the town several years. Later, some oil wells were brought in that until 1902 produced a lubricating oil that sold for $\$ 5$ a barrel.

In 1887, at Sparta, 40 miles southeast of St. Louis, in drilling for water, gas was discovered that supplied the town about 20 years, and in 1906 several oil wells were brought in half a mile northeast of the gas wells.

In 1890, in drilling for water, gas was discovered near Pittsfield, in Pike county, that later developed into a field over 10 miles long.

The present highly prosperous era dates from 1904, when a small gas well was drilled near Casey, in Clark county, by J. J. Hoblitzell, whó was induced to prospect at Oilfield on the showing of oil and gas made by some old wells that had been drilled in 1865 by Chicago parties. The latter drilled several wells on the evidence of oil and gas seepages, but, although a little was found, the wells were a failure from not casing off the water; i.e., they were drowned out. Several more small wells were brought in, but they were so discouraging that they failed to interest the scouts that flocked in when leases were only $\$ 5$ to $\$ 10$ an acre. When a 40-barrel well was subsequently brought in, the "talent" promptly scurried after leases, which rapidly advanced to $\$ 100$ to $\$ 200$ an acre, and since then the Eastern Illinois field has rapidly developed along the La Salle anticline. The southern extension was discovered in February, 1906 , in Crawford county and by midsummer the adjoining Lawrence county began producing. The Allendale pool, at the south end, was discovered in September, 1912. "Shipments by tank cars started in June, 1905 , and within a year the first pipe line reached the field, followed by four others that had a daily capacity of 112,000 barrels by 1909 .

On the western side of the State, the Butler oil and gas was discovered in 1907, the Centralia pool in 1908, the Greenville, Carlinville, and Sandoval pools in 1909, and the Carlyle pool in 1911.

1 Geological Survey of Illinois, vol. iii (1868).

2 Oil and Natural Gas in Illinois, Proceedings of the Illinois Society of Engineers and Surveyors, vol. ii, p. 92. (1887).

${ }^{3}$ Engineering and Mining Journal, vol. xlviii, No. 26, p. 565 (Dec. 28, 1889). 
The total production to Jan. 1,1914 , is $209,018,914$ barrels, valued at $\$ 156,025,398$, as shown in Table $I$. This record for output and values has never been equaled by such a young field, as it requires time, as well as capital, to develop a new field, especially where there was such a lack of confidence. While the latter has disappeared since 1906 on the eastern side of the basin it still holds as regards the western side of the basin.

\section{Table I.-Summary of Illinois Oil Production}

\begin{tabular}{rrrrrr} 
Year & $\begin{array}{c}\text { Output- } \\
\text { Barrels }\end{array}$ & \multicolumn{1}{c}{ Value } & $\begin{array}{c}\text { Stocks Dec. 31 } \\
\text { Barrels }\end{array}$ & \multicolumn{2}{c}{$\begin{array}{c}\text { Produc- } \\
\text { ing Wells }\end{array}$} \\
1905 & 181,084 & $\$ 116,561$ & $\ldots \ldots \ldots$. & 189 & $\begin{array}{r}\text { Price } \\
\$ 0.64\end{array}$ \\
1906 & $4,397,050$ & $3,274,818$ & $2,509,598$ & 3,093 & .75 \\
1907 & $24,281,973$ & $16,432,947$ & $15,751,305$ & 7,353 & .68 \\
1908 & $33,686,238$ & $22,645,881$ & $29,209,660$ & 10,372 & .67 \\
1909 & $30,898,339$ & $19,788,864$ & $32,343,887$ & 11,152 & .64 \\
1910 & $33,143,362$ & $19,699,383$ & $31,324,784$ & 12,171 & .59 \\
1911 & $31,317,038$ & $19,734,339$ & $24,063,870$ & 12,753 & .63 \\
1912 & $28,601,308$ & $24,332,605$ & $15,709,738$ & 13,222 & .85 \\
1913 & $22,512,522$ & $30,000,000$ & $5,613,372$ & $14,000 ?$ & 1.32
\end{tabular}

Total.... 209,018,914 \$156,025,398

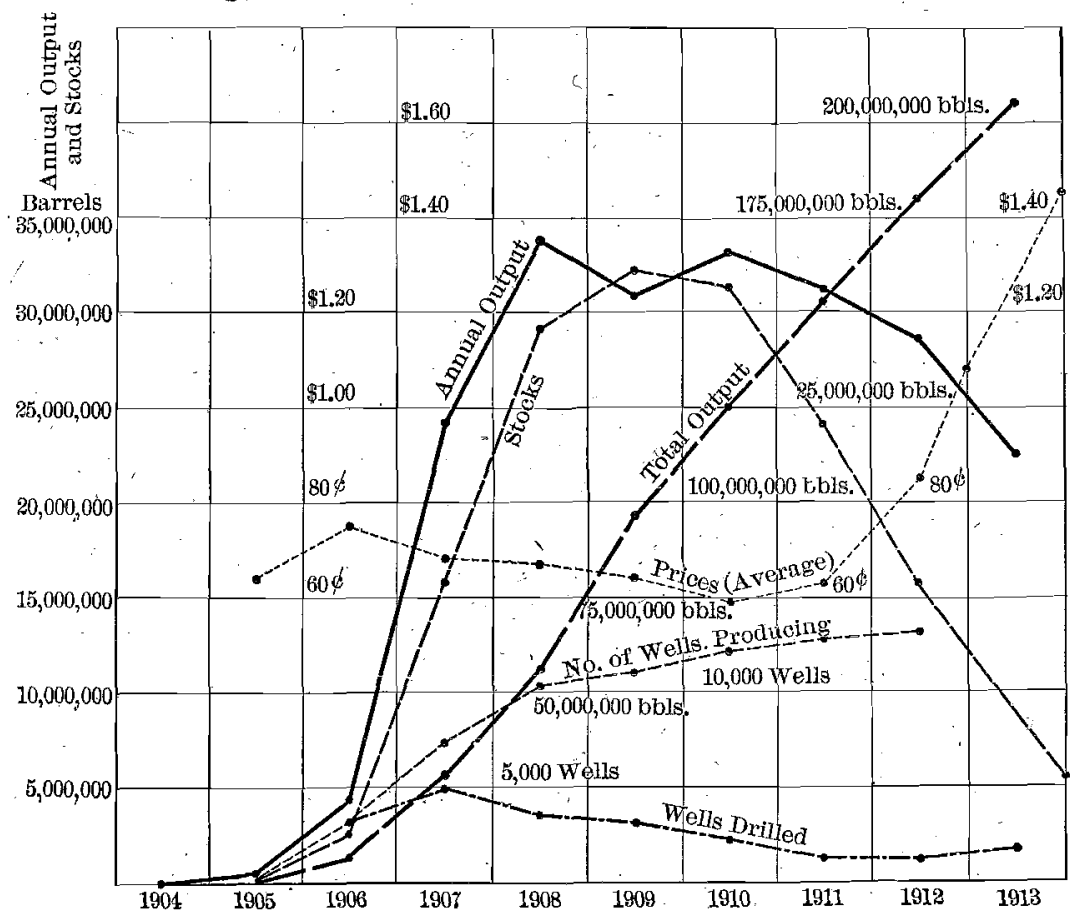

Fig. 1.-Chart Showing Output, Stocks, Prices, and Welis, Illinois Oir Fields. 
Since 1904, 21,730 wells were drilled up to Jan. 1, 1914, of which 82.9 per cent. were producers, that came in with an average daily production of 38.5 barrels per well, aceording to the monthly statistics published by the Oil City Derrick (Oil City, $\mathrm{Pa}$.). This average is based on tank gaugings, and while it is much below the popular estimates, it is high compared with the other high-grade oil fields. The value of wells averaging 38 . barrels will be appreciated when it is considered that a 100-acre lease in Illinois that averages 10 barrels per well usually nets 100 to 125 per cent. on the investment.

A condensed résumé of the Illinois oil statistics is presented in the diagram, Fig. 1, which shows the annual production, the total production, surplus stocks, average annual prices, the oil wells drilled, and the number of producing wells.

\section{Location}

The Illinois oil fields are in the southern half of the State and consist of two groups, known as the Eastern and the younger Western fields.

The Eastern Field.-The Eastern field is situated along the eastern edge of the State and mainly in Clark, Crawford and Lawrence counties, with slight extensions into Edgar, Coles, Cumberland, Jasper, and Wabash counties. The strike is quite regular and runs about $20^{\circ}$ west of north. The-length in Illinois is 66 miles from the Westfield pool at the north end to the Allendale pool at the south end. The field crosses the Wabash river at St. Francisville and extends 45 miles through the southwestern portion of Indiana and continues 50 miles southward to Hartford, in Kentucky, where several wells were brought in last summer. This gives a length of over 160 miles along the La Salle zone of deformation on which oil and gas have been developed. A marked change occurs beyond the Illinois border, as the field becomes very irregular and highly spotty, at least as far as developed, and lacks the remarkable reliability and continuity that characterize it in Illinois. The width of the field ranges from 2 to 4 miles at the northern end and from 5 to 12 miles in the central and southern portions. The field seems to be over 20 miles wide in Crawford county, but this is undoubtedly due to a cross anticline, the influence of which is seen in the new pools being opened in Sullivan county, Ind., which adjoins it on the east.

The accompanying three maps, Fig. 2, illustrate the development of the field when respectively two, four, and nine years old. They show that it is premature to define the limits, as the boundaries are constantly extending, and new sands are being brought in. A study of these maps shows that at the end of two years, when about 4,000 holes had been drilled, apparently less than 25 per cent. of the area along the anticline was productive. At the end of four years, when about 12,000 holes had been drilled, fully 50 per cent. was found to be productive. At the end 
2 YEARS 'OLD-4,000 WELLS

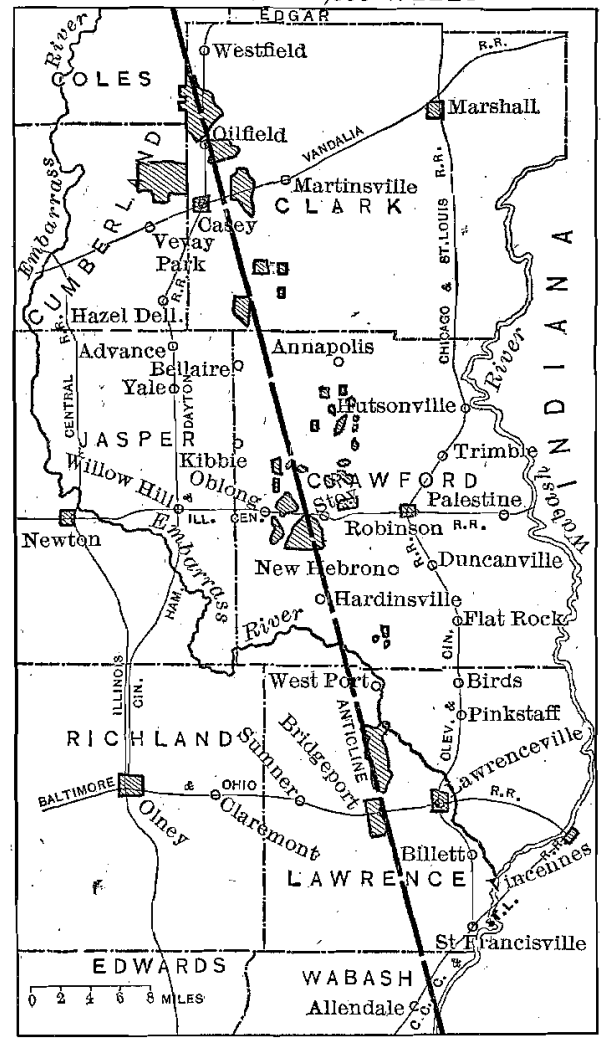

4 YEARS OLD-12,000 WELLS

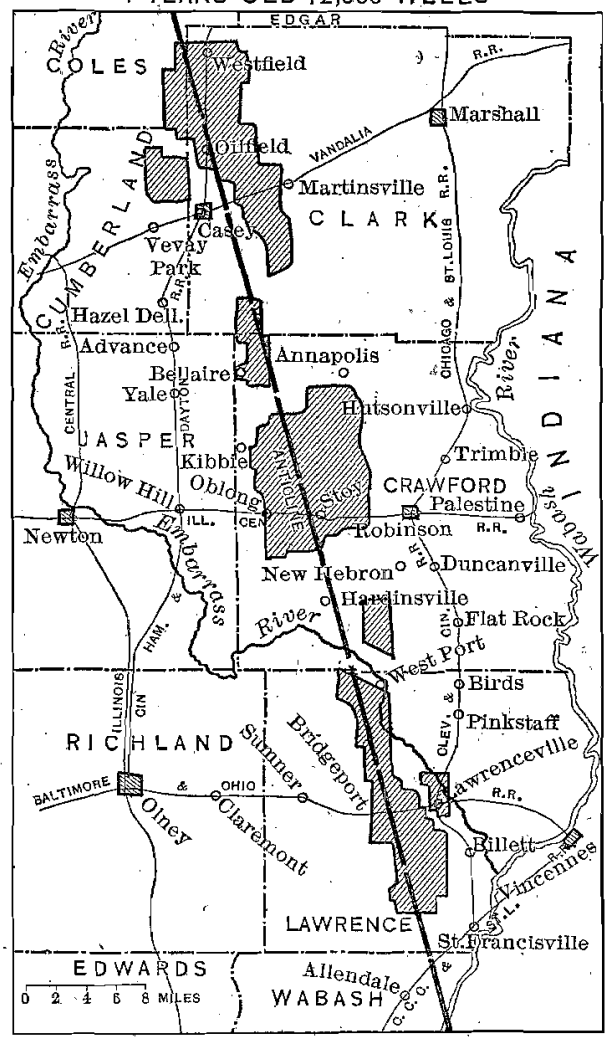

9 YEARS OLD-21,000 WELLS

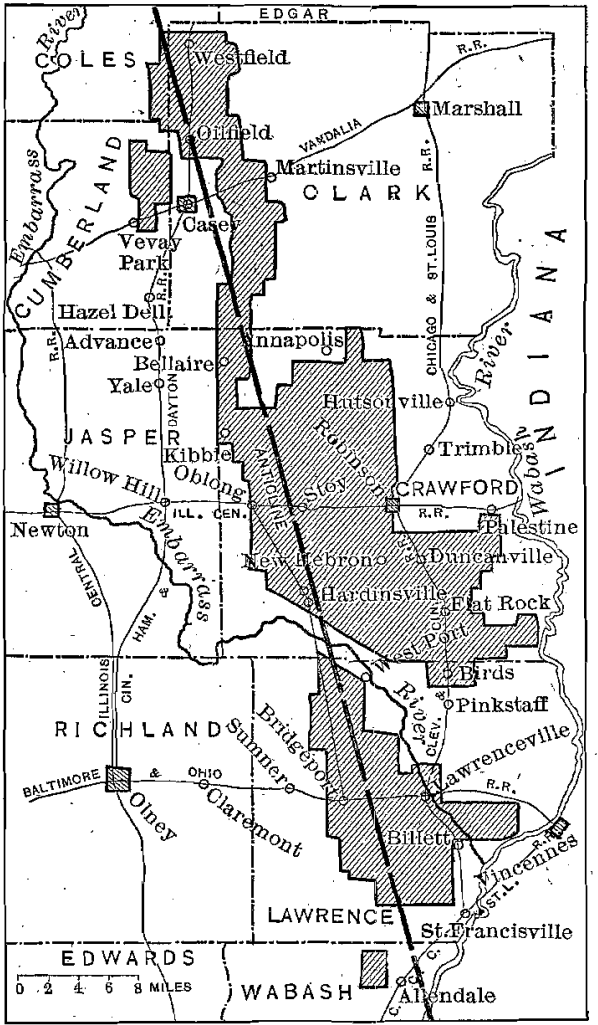

Fig, 2.-Defelopment of the Eastern Illinots Oil Field, Opened in 1905. 
of nine years, when about 21,000 holes had been drilled, over 80 per cent. had proved productive. The Eastern Illinois field to-day is the largest, most regular, and most reliable individual oil field in the United States. If the Allendale pool is omitted, there is only one break in its

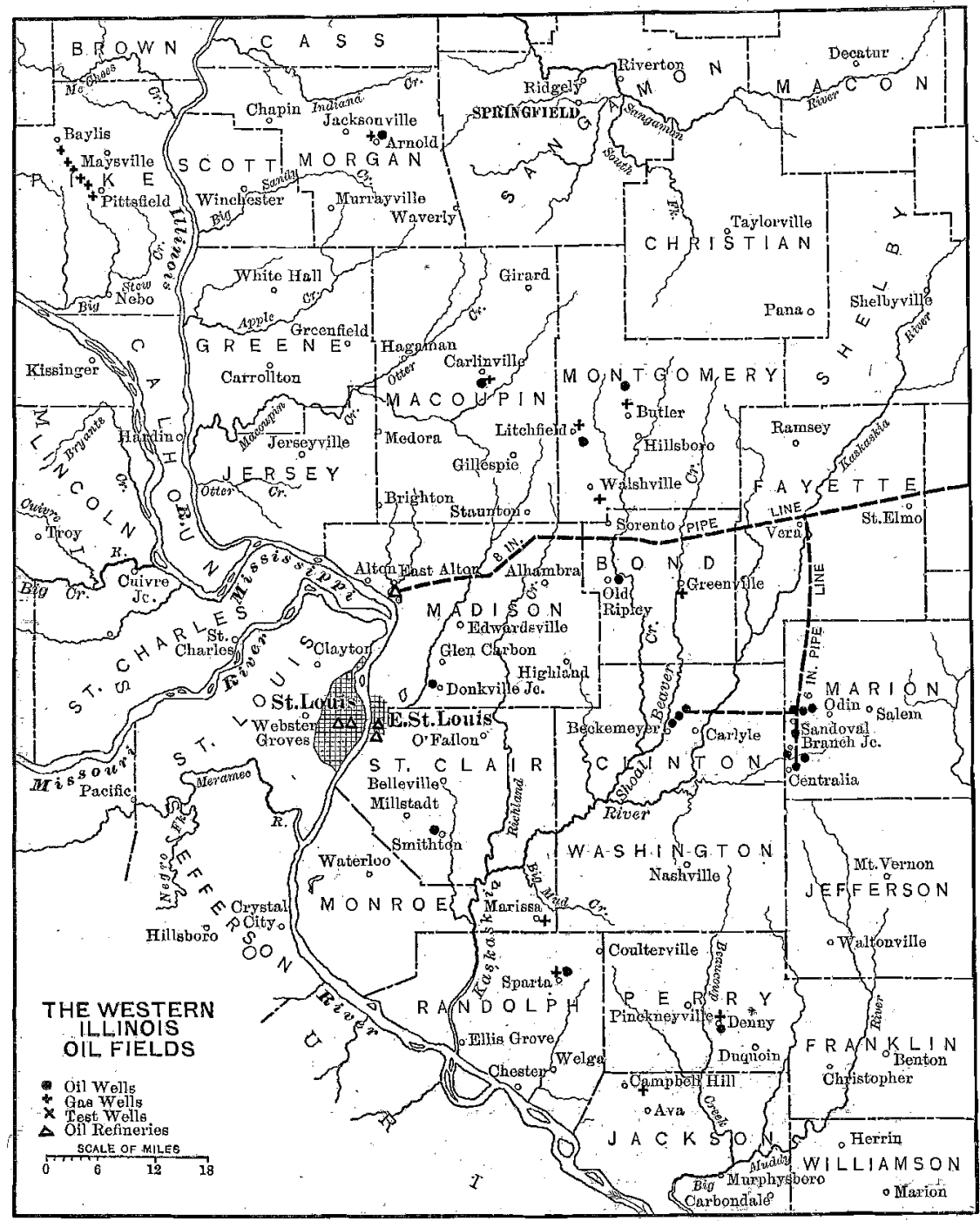

Fig. 3.-Map Showing Westerin Iilinois Oll Fibld.

continuity in 60 miles, or where the Embarrass river crosses the anticline. While to-day several miles separate the Allendale pool from the main field, more thorough drilling may show that the intervening ground 
is productive, as this has repeatedly happened in the past eight years' experience.

The Western Field.-The Western Illinois oil and gas field is situated in Marion, Clinton, Bond, Montgomery, Macoupin, Morgan, Pike, Madison, St. Clair; Randolph, Jackson, and Perry counties, as shown on the accompanying map, Fig. 3 . As the western flank of the İlitinois basin is about three times larger than the eastern, and as there are more anticlines, it will probably develop into a larger field and ultimately produce more oil, although this prediction to-day seems as rash as earlier ones made by the writer that have since made good. For the sands and other favorable formations are practically identical on both sides of the basin, while the more numerous western anticlines have a much larger collecting area to supply them. As the Western field lacks the simplicity and regularity of the Eastern field, it will be more difficult to prospect and the percentage of dry holes will be larger, especially if developed in the haphazard manner in which most prospecting is carried on by "practical" oil men. For the attitude of most oil operators toward the aid that can be rendered by geology and trained experience is similar to that of the steel maker 50 years ago about a chemist-" an amusing scientific chap who uses big words but knows nothing about making steel.",

\section{Geology}

Structure--The geological structure of Illinois is comparatively simple and regular, like its topographic features, which latter mainly consist of a very slightly undulating sheet of glacial drift 50 to $150 \mathrm{ft}$. thick through which occasional sluggish streams have sometimes eroded to bed rock.

- Under the flat prairie surface occurs a spoon-shaped basin. Its north-and-south axis is 400 miles long and its width is 140 to 180 miles. The basin is occupied by alternating sediments, mainly of Carboniferous age, that have a maximum thickness of about $2,000 \mathrm{ft}$. The formations thin out, die out, and outcrop toward the north and thicken and increase in number toward the south. The oil-bearing "sands". tend to decrease in richness toward the north, as a result of this thinning of the beds, and tend to enrich toward the south, from the thickening of same, until they come within the malignant influence of the Ozark uplift. Thinning and impoverishment of the oil sands toward the north also occur in the similar Mid-Continent oil field (Oklahoma and Kansas), in which the present production is also derived from the coal measures, and a similar uplift ruins the southern end of the field.

Upon the flanks of the Illinois basin occur anticlines, or folds, or elongated domes, which in water-charged sediments are the natural traps, or zones of arrest, or concentration areas, of oil and gas. The 
anticlines vary considerably in the amount of the doming and are relatively flat and broad compared with those of Pennsylvania. They are usually flatter and less persistent in the Western field and tend more to the type of a series of domes along the uplift, rather than a continuous ridge type as in the main Eastern field.

Coal Measures.-The oil thus far produced in Illinois, with minor exceptions, is derived from the Carboniferous system, or the coal measures, which consist of alternating shales 5 to $1.50 \mathrm{ft}$. thick, limestones 2 to 50 $\mathrm{ft}$, bituminous coals 1 to $8 \mathrm{ft}$., and sandstones 5 to $60 \mathrm{ft}$. The accompanying well section illustrates the variety and thickness of the formations, in which only the basal sandstone (the Ferruginous, or Benoist) carried oil at this particular place. The six sandstones between 915 and 1,439 ft. frequently contain oil at other places, especially in Lawrence county, while two shallow sands did not show in this well, of which the Dykstra $(600 \mathrm{ft}$.$) produced oil 2$ miles west of this hole.

The shales fluctuate greatly in color, texture, and thickness and are always the predominating formation. The limestones are usually thin and, with one exception, are not persistent. The coal seams are generally thin, or 1 to $3 \mathrm{ft}$, excepting No. 6, and occasionally Nos.' 5 and 2, which range from 4 to $8 \mathrm{ft}$. The thin seams are not persistent, while No. 6 is remarkably persistent in western Illinois and is easily recognized by its limestone roof. The sandstones are usually porous, are firm and stand up well, and are generally water-bearing. The porosity varies considerably, and to a less extent the fineness of grain, which largely explains the variations of different wells in the same field when not complicated by a variable thickness.

\section{Type Section of an Illinois Oil Well}

The Langewich Well, Centralia; 70 Barrels

Formation

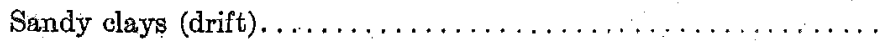

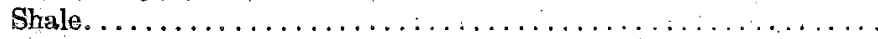

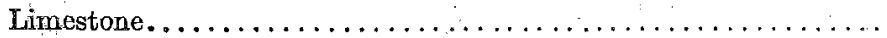

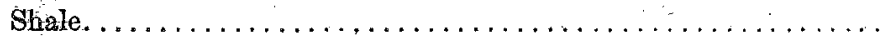

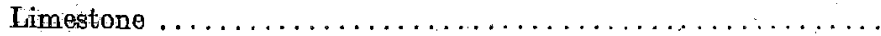

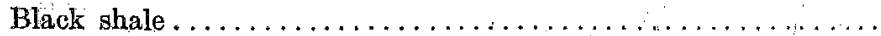

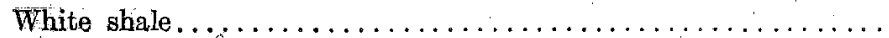

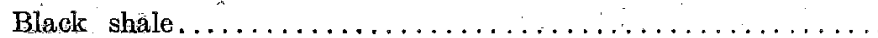

White shale $\ldots \ldots \ldots \ldots \ldots \ldots \ldots \ldots \ldots \ldots \ldots \ldots \ldots \ldots \ldots \ldots$

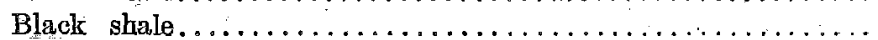

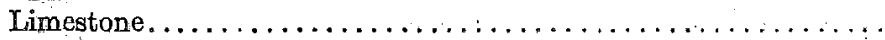

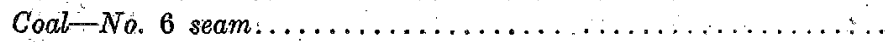

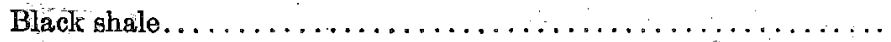

Iimestone.
Thickness Depth

Feet Feet

155

10

10

90

20

67
155

165

175

265

285

352

360

475

500

615

625

632

650

675 
Formation

White shale.

Dark shale.

Coal No. 5

Black shale

White shale.

Black shale.

Limestone

Black shale

Limestone

Sandstone-dark

Black shale.

Sandstone-salt water.

Black shale

Sandstone-salt water

Black shale

Limestone-hard

Black shale

Limestone and shale.

White shale.

Black shale

Sandy limestone.

Sandstone-dark

Dark shale

Sandstone - white

Limestone.

Shale

Sandstome.

"Red rock" (shale).

Dark shale.

Limestone

White shale

Limestone

"Pencil slate" (caves).

"Red rock". (shale)

Shale.

Oil sand $-9 \mathrm{ft}$. pay

(The "big lime" is probably at 1,650 to $1,700 \mathrm{ft}$.)
Thickness Depth

Feet Feet

40

715

748

753

795

845

875

887

900

915

930

1,010

1,021

1,037

1,080

1,100

1,125

1,176

1,226

1,250

1,295

1,305

1,343

1,368

1,393

1,410

1,424

1,439

1,450

1,455

1,485

1,515

1,522

1,552

1,560

1,592

1,631

Sub-Carboniferous.-The following successively deeper measures occur in Illinois, some of which have an-assured future as oil producers:

The Sub-Carboniferous, or the Mississippian, immediately underlies the coal measures and is 500 to $1,000 \mathrm{ft}$. thick. It consists mainly of limestones and is known as the "big lime" by the drillers. An upper bed (the St. Genevieve) that is known as the "McCloskey sand" is occasionally oölitic and has proved the richest in the State, as the wells occasionally come in at 1,000 to 4,000 barrels.

Weneath the "big lime" occurs a shale bed that when sandy was found to carry oil and gas along a small anticline in St. Louis on the 
western fringe of the basin. Like all thick limestones, even when mostly non-magnesian, like this, there is always the possibility of crevices and chambers serving as reservoirs for oil accumulation that are likely to produce good wells. While such reservoirs are erratic and will be difficult to find, they suggest occasional wells. The 200 water wells drilled about St. Louis in this formation occasionally show oil, which indicates that where artesian conditions have not washed away the oil valuable wells will be found.

Where a fault has exposed the "big lime" as a bold bluff near Grafton, 30 miles northwest of St. Louis, it is soaked with oil for about $125 \mathrm{ft}$. This "oil in sight" stimulated considerable drilling in the neighborhood that resulted in dry holes, as the oil that once filled the limestone escaped millions of years ago through the "knocking out of the head of the barrel" by the fault. This exposure is highly important in almost assuring large wells when this horizon is tapped under a thick cover with favorable structural conditions.

Recently wells of 10 to 25 barrels $^{4}$ have been found in Oklahoma in the "big lime,"although the prospect drilling in that field, as in Illinois, has almost invariably stopped at the top of this formation. As the geology of the Oklahoma and Illinois fields is similar in many respects, the developments in either field are likely to prove helpful in prospecting the other.

The Devonian.-The Devonian formation is usually thin, or 2 to 10 ft., where it outcrops along the Mississippi river, on the western edge of the basin, and is generally a black shale. It has been found over 100 ft. thick, and when sandy is likely to be an important, though erratic, producer of oil. Some oil of excellent grade, or $39^{\circ}$ B., was found in the Devonian at Old Ripley, in Bond county, 40 miles northeast of St. Louis, at 2,000 ft., and also at Peters, 10 miles northeast of St. Louis, at $1,300 \mathrm{ft}$., but at both places the sand was very thin and hence the wells were small.

The Niagara Limestone.-The Niagara limestone is 50 to $200 \mathrm{ft}$. thick. The Pike County gas field at $150 \mathrm{ft}$. in western Illinois and the recently developed deep sand $(2,800 \mathrm{ft}$.) at Casey, in eastern Illinois, are in this formation. The famous old crevice well at Terre Haute, Ind., 30 miles east of Casey, also is in the Niagara lime. Where this limestone is dolomitic, and consequently porous, as in Pike county, it is likely to prove a productive horizon if anticlines or other structural conditions are favorable.

The Trenton Limestone.-The Trenton is 200 to $400 \mathrm{ft}$. thick and is partly a porous dolomite and partly a compact limestone. A shale that occurs with it is so heavily soaked with oil as to burn líke a candle and is known as "oil rock" where it outcrops for about 300 miles along the

"Since the above was written, a 250-barrel well has been struck at Big Heart, Okla., at a depth of $300 \mathrm{ft}$. in the "big lime" and with a surface depth of $2,200 \mathrm{ft}$. 
wostern fringe of the basin. 'This is the formation that carries the oil and gas in the adjoining Indiana field and also in the Lima field, of western Ohio. As it is usually 2,500 to $3,500 \mathrm{ft}$. deep in southern Illinois and has a thick shale cover, it is likely to be a rich gas producer, as the great depth has probably prevented leakage. It is a promising formation for both oil and gas and underlies the entire oil field, though at varying depths.

Very Deep Sands.-About 200 to $400 \mathrm{ft}$. below the Trention occurs the St. Petcrs sandstone, which is usually 100 to $200 \mathrm{ft}$. thick and generally coarse and very porous. Still deeper are the "second" and "third" sandstones, that are interbedded with magnesian limestones. While these are possible oil horizons, there aro fcatures that are not encouraging, while the depth will be 4,000 to $5,000 \mathrm{ft}$.

Oil Conditions.-The chemical, physical, and structural conditions in Illinois are ideal for the occurrence of profitable oil pools, and the geologists incurred little risk in predicting their discovery many years in' advance of the drill. For there is an abundance of material to produce the oil in the bituminous shales, organic formed limestones, and coals. There are numerous porous beds to act as reservoirs in the porous sandstones and dolomites. There are many shales to act as impervious covers, or "stoppers to the bottle." There is a continuous dip on the sides of the basin to permit gravity to rearrange the original concurrent association of water, oil, and gas. There are anticlines to trap or arrest the ascending oil and gas and concentrate them into pools, and the magnitude of the basin is sufficient to insure large pools. Stratigraphic conditions have prevented artesian circulation, at least in the lower sands, thus preventing the washing away and dissipation of the oil after reaching the anticlines. Faults and dikes are either absent, or are so slight in the main part of the basin as not to interfere with the accumulation of the oil, or to cause its dissipation. While these conditions have been known to the geologist for a long time, it is only since 1905 that they have been demonstrated to the satisfaction of the oil operators on the eastern side of the basin. Tho oil men are still skeptical as to the western. field, which is only in the infancy of its development, and they have thus far lacked the courage to test the deeper horizons below the coal measures.

\section{Description of the Eastern Illinois Field}

The Eastern field is situated along a strong anticlinal fold known as the "La Salle," as it passes through the town of La Salle in northern Illinois, where it is a heavy fault. As the axis of the anticline dips south, the sands deepen and increase in number and thickness to the southward. The No. 6 coal seam, which is well marked and persistent in western 
Illinois, serving as a valuable datum plane, is frequently absent in eastern Illinois, or is difficult to recognize, so that the correlation of the "sands" is uncertain. All of the sandstones (or "sands") are more or less lentioular, as usual, or thicken and thin, come in and die out; although two of them are surprisingly persistent.

The field is divided into three districts, each of which has marked individuality, which are known as: 1, the Clark County, or Northern, or Shallow, district; 2, the Crawford County, or Central, district; and 3, the Lawrence County, or Southern, or Deep, district.

The Northern District.-The Northern district is mainly in Clark county, with slight extensions into Edgar, Coles, and Cumberland counties. Casey is the commercial center, which, like the other towns in the oil belt, has greatly grown and prospered since the field opened in 1905 .

Most of the wells are 350 to $400 \mathrm{ft}$. deep and are in a light gray, porous, dolomitic limestone that has 8 to $30 \mathrm{ft}$. of pay. The wells come in at an average of 25 barrels; ranging from 5 to 50 and occasionally at 100 to 200 barrels per day. The small cost of a well resulted in considerable over-drilling, with a consequent rapid decline, and many wells were abandoned when they fell off to one to two barrels with oil selling at 60c. to 68c. Recently the abandoned leases have been re-drilled and again made very profitable, especially as another oil horizon has been found 40 to $100 \mathrm{ft}$. deeper, that comes in at 10 to 50 barrels.

In the Siggins pool, 2 miles west of Casey, a sand occurs at $600 \mathrm{ft}$. that is 20 to $60 \mathrm{ft}$. thick and came in with 10 to 100 barrel wells and plenty of gas.

Oil shipments by rail began in June, 1905, and in the following three years the field developed rapidly." Since then the extensions have been slight and there was little activity until last year, when a second pay was found at about $450 \mathrm{ft}$. The district is producing about 7,000 to 8,000 barrels daily.

Recent deep drilling near Westfield, at the northern end of the field, has found a dark-green, high-paraffine oil at 2,750 ft. As the wells are small for such a deep sand, or 10 to 20 barrels thus far, only a few have been drilled and they are on the western edge of the pool. They are probably in the Niagara limestone, as are the Terre Haute well, 30 miles east, and also the Pike County gas field, in western Illinois.

The Crawford County District.-The Central; or Crawford County, district, with Robinson as the commercial center, is the largest in area and has made the highest output, as 100,000 barrels a day were produced in 1907. It occupies the greater part of Crawford county, with a slight overlap into Jasper county on the west, and extends to Indiana on the east. The great width of over 20 miles that the field seems to have is undoubtedly due to a cross anticline that extends into Sullivan county, Ind. 
The main producing horizon occurs at about $900 \mathrm{ft}$. and is known as the Robinson sand. It ranges from 8 to $30 \mathrm{ft}$. in thickness, averaging $20 \mathrm{ft}$., and the wells come in with an average of about 30 barrels per day, ranging from 5 to 100 and occasionally 200 to 500 barrels. A sand known as the Kibbe occurs at $750 \mathrm{ft}$. in the northern part of the county; and deeper sands occur at 1,100 and 1,400 ft. (the latter resting on the "big lime") over portions of the field, but they are narrower and less reliable than the Robinson sand.

The district was opened in February, 1906, by the discovery of the rich Shire pool, near Oblong, as the result of wild-catting started by a salted well. The latter opened the field at least a year earlier than would have resulted from conservatively edging southward from the Casey district. Four very active years of drilling followed, that rapidly enlarged the field, and for the past six years it has been a consistent producer, as the average well came in at 22 to 28 barrels. There has been considerable over-drilling, especially where the early wells were large, and the wells have therefore declined to a very moderate production. The daily output of the district is about 12,000 to 15,000 barrels.

A local, but unsuccessful, company drilled several tests about Robinson in 1901 to 1903, that found trifling amounts of oil and gas. Developments since then show that some of the holes were located in the pool, and had intelligent advice been secured the efforts would have been rewarded with huge profits. This experience of the pioneers failing where later followers have reaped generous rewards has been repeatedly duplicated in Illinois. Within the past few months town-lot wells are being drilled in Robinson, which was condemned by the earlier oil men from the neighboring dry holes. Another very reliable pool, where 42 good wells were consecutively brought in on one lease, was discovered 18 months ago in the heavily condemned territory 3 miles north of Robinson.

The Lawrence County District.-Lawrence county, at the southern end of the field, is probably the richest producer of high-grade oil of any county in the world. A few pools have attained a larger initial production, but the nine sands and their great staying power have enabled Lawrence county to maintain a daily production of 40,000 to 60,000 barrels for the past seven years. Yet the first three tests were dry holes in what has since proved to be the heart of the pool. The old oil operators were afraid of it and promptly sold out in its early development, as there was no gas. It occupies the greater part of Lawrence county, with a small extension to Allendale on the south, in Wabash county. Bridgeport is the commercial center, where the field was opened in 1906 with townlot wells. The latter are still profitable producers, which is one of the rare exceptions where such excessive well density has paid.

The development of the field has been steady and consistent, as the depth and high cost of drilling have discouraged over-drilling. The voL. XIVIII.-35 
first wells were opened in the Bridgeport sand at about $900 \mathrm{ft}$., which came in at 20 to 100 barrels; later, other lenses of Bridgeport sands were developed at 780 and 1,000 ft. Later drilling brought in the Buchanan sand at 1,300 to $1,400 \mathrm{ft}$., the "Green Oil" at 1,525 to 1,575 ; the Kirkwood at 1,590 to 1,625 ; the Tracy at 1,700 to 1,790 , which has produced wells of 1,000 to 2,000 barrels; and the MeCloskey at 1,840 to 1,900 ft. The latter is an oolitic limestone, the St. Genevieve, in the upper portion of the Mississippi lime, and is very rich, as it has produced 2,000 to 4,000 barrel wells; the oil, like the Tracy sand, has a gravity of $37^{\circ}$ to $39.5^{\circ}$ B. Recent developments have brought in the Richey sand, at $550 \mathrm{ft}$., that was overlooked in the earlier work.

Three to five of the above sands are often found productive on one lease, to each of which separate wells were formerly drilled. In recent practice, one well is made to serve several sands by perforating the casing at each horizon.

The Allendale pool, in Wabash county, was discovered in September, 1912. Only one sand has thus far been found, at 1,500 ft., which produces a $37^{\circ}$ gravity oil, but with no gas. The wells come in at 20 to 800 barrels, but decline rapidly, and the pool is small and spotted.

The daily output of the Lawrence County district ranges from 42,000 to 50,000 barrels.

\section{Description of the Western Illinois Field}

The Western Illinois oil field is so much younger than the Eastern field, with two minor exceptions, that the output is much less, although the sands are essentially the same and also the grade of oil. The developments of the next five years will probably witness a large increase in the output, and ultimately it will probably surpass the eastern side of the basin. For the western flank is about three times as large as the eastern limb of the Illinois basin and the anticlines are more numerous. It will develop less rapidly, however, as it lacks the simplicity of the Fastern field, espeeially if prospeeted in the erratic, unscientific method usually pursued.

Marion County. - In sinking a coal shaft 2 miles north of Centralia, in 1908, oil seeped in at $600 \mathrm{ft}$. from a small fault, which stimulated drilling in the vicinity. A strong north-and-south anticline at this place had been previously mapped by the Mlinois Geological Survey, but, as usual, this was ignored by the oil men. Several 5-barrel to 20-barrel wells were brought in near the shaft in the Dykstra, or 600-ft., sand.

In the following year two light wells were brought in 2 miles east of Centralia in the 1,600-ft., or Benoist, sand and 75-barrel wells since then; the $\log$ of one of these, the Langewich well, is given on a preceding page. In the Dunn well, 2 miles northwest of Centralia, the oil was found in the Stein, or 1,400-ft., sand. Another oil sand, though light, was reported 
at $1,300 \mathrm{ft}$. in the Wireback well that was drilled last fall $2 \frac{1}{2}$ miles east of Centralia, in which the Benoist sand was found at $1,685 \mathrm{ft}$. ; this is unusually low and explains why the oil was light and the salt water heavy, as it was too far down on the anticline (too far east) to expect oil. It is difficult to obtain reliable information about the Centralia pool and it has the earmarks of being held back until more leases are obtained.

Prospecting for the extension of the Centralia pool in 1909 brought in a good well at Sandoval, about 6 miles north on the same anticline, and in the following year a rich pool was drilled in. A sand was struck at about $1,400 \mathrm{ft}$. (the Stein) that came in at 25 to 50 barrels and at 1,550 $\mathrm{ft}$. the Benoist sand came in with wells of 50 to 400 barrels and averaged 110 barrels per day. As the Benoist sand is 20 to $40 \mathrm{ft}$. thick and has great staying power, the wells are all sunk to this horizon and production in this field is the highest priced in the State. There is plenty of gas in both sands, and the No. 6 coal seam is found at $600 \mathrm{ft}$. The Benoist sand rests on the "big," or Mississippi, lime.

The Centralia district is connected by a 4 -in. and the Sandoval district by a 6 -in. pipe line with the Ohio Oil Co. lines, while Sandoval also has a 4-in. independent line to loading racks on the B. \& O. R. R.

Marion county has the highest record in the State for initial production, as the U. S. Geological Survey statistics ${ }^{5}$ for 1910 show that 60 wells came in with an average daily output of 110.6 barrels; Lawrence county is second, at 102.7 barrels in 1910 and 105 barrels in 1912, when the very rich McCloskey sand was discovered.

Clinton, County.-In prospecting in 1910 along an anticline near Carlyle, to which attention has been drawn by the Illinois Geological Survey, a 100-barrel well was brought in at 1,020 ft. after three previous failures. Hundreds of oil men rushed in and bought up leases in every direction, paying $\$ 5$ to $\$ 10$ an acre 10 miles distant up to $\$ 250$ an acre near the discovery well. A rich pool was rapidly developed and the wells came in at 20 to 1,000 barrels per day, with plenty of gas. Another sand at $800 \mathrm{ft}$. that was overlooked in the first rush has since been developed and came in at 10 to 30 barrels.

The Carlyle pool is connected by a 6 -in. pipe line with the Ohio Oil Co. lines.

The 123 wells brought in during 1911 in Clinton county came in with an average daily output of 95 barrels, the highest in the State that year, and which has only been exceeded by the adjoining Marion county at 110.6 barrels (the highest in the State), and by Lawrence county (eastern Illinois) at 105 barrels in 1912.

Bond. County.-Drilling at Greenville in 1910 developed a gas sand at $950 \mathrm{ft}$. that has since furnished light and heat for that town, the wells coming in at 2,500,000 cu. ft. per day.

' Production of Pelroleum in 1912, U. S. Geological Survey, p. 68 (1913). 
Subsequent drilling at Old Ripley, 10 miles west of Greenville, found oil at about 2,000 $\mathrm{ft}_{\text {., }}$ in the Devonian formation. The sand was very thin, or about $2 \mathrm{ft}$., and the wells were so small, or 5 to 25 barrels, that they were abandoned, as oil was then selling at $60 \mathrm{c}$.

Montgomery County. -The first commercial gas and oil found in Illinois were developed at Litchfield, at about $600 \mathrm{ft}$, in 1882 . The gas was discovered in drilling for a lower coal seam and it supplied the town for several years. Further drilling in 1886 found several small oil wells that produced until 1903 a lubricating oil that sold for $\$ 5$ a barrel. In drilling for coal at Butler, 8 miles east of Litchfield, in 1907, gas was discovered at $600 \mathrm{ft}$., and two miles north a similar heavy lubricating oil was found in the same sand, but developments were stopped by litigation.

Macoupin County.-Drilling at Carlinville in 1909 found gas and a little oil ( 2 to 5 barrels) at $400 \mathrm{ft}$. in the same sand as at Litehfield and Butler, that has since supplied that town. On drilling half a mile east of the gas wells last summer wells of 40 to 100 barrels wore brought in from the same sand and a local pipe line was built to the field.

Pike County.--In drilling for water near Pittsfield, in 1890, gas was struck at $168 \mathrm{ft}$. in the dolomitic Niagara limestone, but no use was made of it until 1905 . Since then a field 10 miles long by 4 miles wide has been developed along an anticline and nearly every farm has its own gas well.

Randolph County.-In drilling a water well at Sparta; in 1887, a strong flow of gas at $350 \mathrm{lb}$. pressure was struck at $900 \mathrm{ft}$. that supplied that town for over 20 years from some 20 wells. In 1906 oil was found in several wells over a small area on drilling about half a mile northeast of the gas field. While one well came in at 100 barrcls, most of them were small, and shipments have about ceased. An investigation of the well records by the Illinois Geological Survey shows that the wells were drilled on a local "wart" or very small dome in a synclinal basin, which clearly explains the large number of dry holes that surrounded the small oil pool.

Morgan County.-Small amounts of oil and gas were found near Jacksonville, in 1910, at $300 \mathrm{ft}$., which is the most northerly occurrence that suggests commercial value. As the sands thin' and die out going northward, the prospects are not encouraging in northern Illinois.

Madison County. - At Petèrs, 10 miles northeast of St. Louis, excellent oil was found in 1905 , in the Devonian, at about $1,300 \mathrm{ft}$., but as the sand was very thin the wells were too small to pay.

St. Clair County.-At Smithton, several small oil wells were brought in during 1911, at $150 \mathrm{ft}$., at the base of the coal measures, along an anticline that extends northeast through O'Fallon. As the oil sand outcrops a few miles southwest it is surprising that any oil was found, but prospecting northeastwardly along the descending axis of the anticline should be successful when deep enough to be beyond the leakage zone. 
At Marissa, gas and oil were noticed in 1895 in drilling a water well, - which led to further drilling in 1912. Two good gas wells were brought in at $600 \mathrm{ft}$. As the neighboring coal mines show a strong, wide anticline, a field will probably be opened in the vicinity.

Jackson County.-A small gas well was brought in near Campbell Hill at $580 \mathrm{It}$. in 1912 that led to considerable drilling in the vicinity; a little oil was found, but thus far not in paying quantities. This county is so far south as to be within the discouraging zone of faulting caused by the Ozark uplift and hence there is grave danger that the oil and gas have escaped, at least from the large pools that undoubtedly once existed.

\section{Quality of the Oil}

Over 92 per cent. of the Illinois oils grade $\mathrm{a}^{\dagger}$,ove $30^{\circ} \mathrm{B}$., which is the commercial line between low and high gravity oil. The Flat Rock oil is about $22^{\circ}$ gravity, and occasionally oil in the Robinson and Casey sands grades at $28^{\circ}$ B., on which there was formerly a dockage of $8 \mathrm{c}$. a barrel; but for over a year all grades of Illinois oil have commanded the same price.

Broadly, the gravity of the oil improves with depth in Illinois, as the oils from the shallow sands in Clark, Crawford, and Macoupin counties are relatively heavy, or from $28^{\circ}$ to $32^{\circ} \mathrm{B}$., while the oils from the deeper sands in Lawrence, Marion, and Clinton counties will range from $34^{\circ}$ to $39.5^{\circ}$ gravity.

The color of the Illinois oils is very dark green to dark brown, except the deep Casey oil, which is light green and high in paraffine.

The Illinois oils have a paraffine base, except in the Bridgeport and Flat Rock sands, which have as much as 5 per cent. of asphalt.

The oils are "sweet," or essentially free from sulphur, as the latter averages 0.2 per cent., ranging from 0.1 to 0.5 per cent.

The gasoline content, like the gravity, improves with depth, as the Clark County or shallow oils have 8 to 18 per cent., the Crawford county oils have 8 to 20 per cent., and the deep Lawrence county oils have 10 to 23 per cent., while the heavy, asphaltic Flat Rock oil has only 1 to 4 per cent. The average gasoline content is about 15 per cent.

The kerosene content ranges from 25 to 38 per cent. and averages about 31 per cent.

\section{The Oil Sands}

All but two of the so-called "sands", in Illinois are sandstones, and, on account of the dip of the basin, the depth of the same sand will vary according to the distance from its outcrop. On the eastern side of the State the depth increases toward the west, and on the west side, which is much the longer flank, the depth increases eastwardly at 10 to $15 \mathrm{ft}$. per 
mile. There is a secondary general dip of the northern three-fourths of the State to the south, due to the dip of the axis of the spoon-shaped basin to about Jefferson county, when the axial dip reverses, with a much sharper dip to the north, and the southern, or stub, end of the basin comprises about a fourth of the State.

When not carrying oil or gas, most of the Illinois sands are saturated with salt water and dry sands are local. Even on the anticlines, if a sand is thick, oil and gas frequently occur in the upper portion, while the lower part of the sand may be full of salt water.

Two of the oil-bearing sandstones are quite persistent and fairly uniform over large areas of Illinois, while the other sandstones are lenses of greater or less magnitude and consequently are more or less uncerta $\mathrm{n}$. The lenticular, uncertain character of most of the oil sands harmonizes with the other formations of the Illinois coal measures, as, barring No. 6 coal seam and one or two limestones, the limestones, coals, sandstones, and shales fluctuate greatly in persistency and thickness in fact, to such an extent that it is often difficult to correlate reliable logs of different wells on the same lease.

Basal Sand.--The most persistent and easily recognized "sand" rests on the "big lime" and was formerly known as the Ferruginous sandstone. It generally ranges from 20 to $50 \mathrm{ft}$. in thickness, is usually coarse and porous and is the Sparta gas and oil sand, the Benoist sand of Sandoval and Centralia, the "deep" sand of Crawford county, and the Tracey sand of Lawrence county. The wells usually come in at 50 to 150 barrels, ranging from 5 to 1,500 barrels per day.

Robinson Sand.-About 200 to $300 \mathrm{ft}$. above the basal, or Ferruginous, sandstone, occurs another sandstone that is very persistent and more frequently carries oil or gas. This is the "big-pay" sand at Carlyle, the gas sand at Greenville, the oil and gas sand at Litchfield, Butler, and Carlinville on the west side, and is the equivalent of the Robinson sand in Crawford county and the Kirkwood in Lawrence county. This sand is 5 to $50 \mathrm{ft}$. thick, averaging 15 to $25 \mathrm{ft}$., is usually quite uniform, rather coarse, and stands up fairly well. It produces wells of 20 to 100 barrels, with extremes of 5 to 1,500 barrels per day.

Casey Sand.-The 400 -foot, or Casey, sand in Clark county is a dolomitic limestone, which is unusual in the coal measures, as the limestones are seldom magnesian. The dolomitization has rendered it porous and therefore capable of serving as a reservoir. The wells come in at 17 to 30 barrels, with extremes of 5 to 200 barrels per day.

McCloskey Sand.-The McCloskey sand in Lawrence county is an oolitic horizon (the St. Genevieve) in the upper portion of the Mississippian limestone. Its porosity is due to the spaces between the spherical granules of which this formation is composed, and as these are large and excessively numerous it produces very large wells, or from 50 to 4,000 
barrels per day, the largest thus far found in Illinois. The excessive, coarse porosity that is responsible for such large wells also results in the oil soon draining out; hence the wells soon decline to a modest output.

\section{Drilling Features}

Contracting.-Drilling is generally done by contract, as few companies operate their own tools. The contractors furnish the equipment and deliver a completed hole on a footage basis, also including the casing if desired, though usually the latter is supplied by the producer. "Machines," or portable rigs, are generally employed up to 1,200 ft., although some contractors use derricks for the 400-ft. wells. The derrick is used when over 1,200 ft. and is usually wood, though a few composite, or "turn-buckle," rigs are employed, and rarely the all-steel derrick. The derricks are erected by special rig-builders at an expense to the operator of about $\$ 700$, as they are usually left on completion of the well for subsequent cleaning and pulling.

As the fire clays under the coal seams frequently cave and as there are several water sands above the oil, a large amount of casing is required. For wells not over 1,000 to $1,200 \mathrm{ft}$., the hole is started with 10-in. or 12-in. drive pipe; followed by $8 \frac{1}{4}$-in. casing, and the oil sand is entered with $6 \frac{5}{8}$-in. casing; deeper holes are started with 16-in. drive pipe and sometimes finished with $5 \frac{1}{16}$-in. easing. The gas pressure is usually so light that it is imperative to enter the oil sand with a "dry" hole; that is, the overlying waters must be shut off by casing. For if the hole is full of water a rich oil sand might be passed through and reported as a trace, or a "showing," from the hydrostatic pressure holding back the oil in the sand, or "drowning the oil." This is what delayed the opening up of the Casey district some 40 years. When the hole caves, underreaming bits are used, which permits the easing to follow closely after the tools, thus preventing them from getting buried under the cavings. Crooked holes occasionally give trouble from the tools being diverted by striking a "nigger-head," or the tough, hard, spathic iron concretions that occur in some of the shales.

The prices paid for drilling in the Casey and Crawford districts, where machines.are used and there is no caving, range from 70c. to 80c. per foot. In Lawrence county, the rates are 90c. to $\$ 1$ to the Bridgeport sand (900 ft.) and $\$ 1.30$ to $\$ 1.50$ to the deeper sands, where more or less underreaming is, required. In western Illinois, where there is more or less caving, the rates are $\$ 1.15$ to $\$ 1.25$ per foot up to $1,100 \mathrm{ft}$. and $\$ 1.40$ to $\$ 1.50$ to the 1,600-ft. sand. These rates are subject to modifications according to haulage and whether the operator furnishes the fuel and water. For cleaning out the hole, etc., after shooting, the charges are $\$ 20$ to $\$ 25$ a day. 
Drillers are paid $\$ 5$ and back-hands or tool dressers $\$ 4$ per 12-hr. shift, with two men "on tower". while drilling and both crews, or four men, when setting or pulling casing.

For "wild-catting," or drilling at a distance from proven fields, the charges are higher, or usually $\$ 2$ per foot, from the inconveniences and greater delays that result in isolated work.

The time required to complete a hole to the $400-\mathrm{ft}$. sand ranges from 4 to 8 days, as from 30 to $100 \mathrm{ft}$. are drilled per shift. It takes 14 to 24 days to drill to the 1,000-ft. sand and 30 to 60 days to the 1,600-ft. and 1,800 -ft. sands.

Shooting.- Shooting has been the salvation of many Illinois wells that made only a feeble showing until shot, after which they came in at 25 to 50 barrels. Formerly heavy shots, or from 100 to 200 quarts of nitro-glycerine, were used, but so much sand trouble resulted that 20 to 80 quarts are now employed, depending on the thickness and softness of the sand. Several feet of bottom anchor are used where there is danger of breaking into water below.

The shots are fired with a battery, on account of caving trouble, and the charge is placed and wired before the $6 \frac{5}{8}$-in. casing is pulled.

\section{Well Density}

Acreage per Well.-The usual practice in Illinois is to allow about 5 acres to each well, or they are spaced 400 to $425 \mathrm{ft}$. With 10 to $25 \mathrm{ft}$. of fine-grained sand this insures a slow decline and a reasonably long life. When the sands are thin, or so deep as to make the cost excessive, a well is given 7 to 10 acres, or they are spaced 500 to $600 \mathrm{ft}$. apart.

In the shallow sands, where the cost is light, the wells have frequently been placed much closer, or with only 1 to 3 acres to the well. While such over-drilling temporarily gives a large outpat, it results in a rapid decline of the wells and sinks an excessive amount of capital in a needless number of short-lived wells. When the leases are very small, or under 20 acres, or where very large wells are brought in, the rivalry among neighboring operators to secure as much of the oil as possible usually results in over-drilling, to the great advantage of the contractors and supply men, but at the expense of the ultimate profits of the operators. Town-lot wells seldom pay, as four to eight wells are drilled on an acre, which usually exhausts the oil so quickly that the investment is not always repaid. The wells in the town of Bridgeport are an unusual exception, as they have proved quite profitable, which is partly due to the staying power of the Bridgeport sand and partly to there being several sands. For the same reason the 1-acre school leases in Lawrence county, on which two to four wells have been drilled, have paid well.

As an extreme case of excessive well density in a normal field, yet one 
that has proved highly profitable, a sketch, Fig. 4, is shown of the McBride $\frac{3}{4}$-acre tract, 4 miles north of Bridgeport, that has been operated since Jan. 1, 1908, by the Silurian Oil Co. It is surrounded by four leases that call for 22 offset wells and to-day there are 30 wells on an area of less than 2 acres. Yet in 2,190 days it produced 200,000 barrels and to-day is yielding 55 barrels from 8 wells; this gives an average yield to date of 25,000 barrels per well, without including the flush production of 1907. Five wells are in the Bridgeport sand and three in the Buchanan, which are very thick, or 35 to $45 \mathrm{ft}$., which explains their

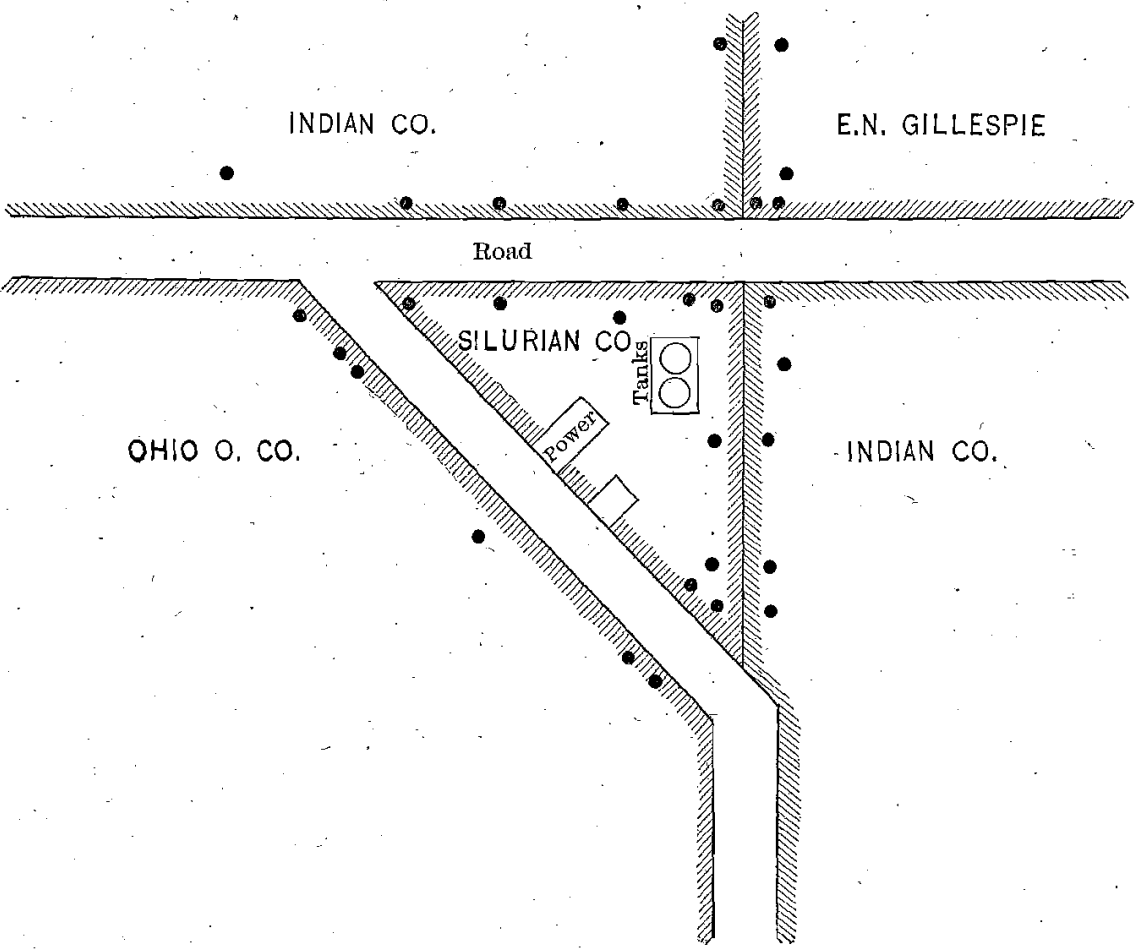

Fig. 4.-Thirty Wells on Two Aches, near Bridgeport, Ill.

ability to stand such a very heavy drain; they came in at 35 to 300 barrels. The sales from a gas well in the Kirkwood sand (No. 9) that came in at $5,000,000 \mathrm{ft}$. exceed $\$ 20,000$.

To illustrate the richness of this territory when not overtaxed by excessive well density, a neighboring 40-acre lease produced 1,069,347 barrels in about 2,300 days from 17 wells in three sands, or over 60,000 barrels per well, and the wells are tanking 445 barrels per diem.

Offset Wells.- The unwritten law to locate line or boundary wells $200 \mathrm{ft}$. back from the property line has been quite well lived up to, and 
there have been few line fights, outside of town-lot and similar small leases where disputes are unavoidable. The offset wells have usually been promptly drilled, especially in the early days when the wells were larger, and the drill is generally kept busy in developing a lease until all the line or boundary wells are completed. The inside locations are subsequently drilled deliberately and on many 40-acre and 80-acre tracts they have been omitted, as it is found that the line wells will eventually drain the interior of the lease.

\section{Plant Equipment}

Casing.-Casing is the heaviest investment on a lease and ranges from $\$ 1$ to $\$ 1.50$ a foot up to $1,000 \mathrm{ft}$.; and from $\$ 1.50$ to $\$ 2.50$ in deep holes, or 1,400 to 1,900 ft. Formerly all the casing was left in a hole, but the larger sizes, or above $8 \frac{1}{4}$-in., are now pulled and re-used. Casing requirements vary with every hole, but the following approximations cover most cases: A 1,000-ft. hole will require 50 to $200 \mathrm{ft}$. of 10 -in. to reach the rock; from 200 to $600 \mathrm{ft}$. of $8 \frac{1}{4}$-in. to shut off the upper waters; from 800 to $1,000 \mathrm{ft}$. of $6 \frac{5}{8}-\mathrm{in}$. to reach the oil sand. A $1,600 \mathrm{ft}$. hole will require 50 to $150 \mathrm{ft}$. of 16 -in.; from 200 to $600 \mathrm{ft}$. of $12 \frac{1}{2}$-in.; from 600 to $1,000 \mathrm{ft}$. of 10 -in.; from; 1,000 to $1,400 \mathrm{ft}$. of $8 \frac{1}{4}-\mathrm{in}$; and from 1,400 to 1,600 ft. of $6 \frac{5}{8}$-in. Occasionally a string of $5 \frac{3}{16}$-in casing is employed to finish a hole, if water sands or the under-reaming have been excessive. The price of casing, which is subject to great variation, is about as follows, to which 5 to 20 per cent. should be added for freight, unloading, hauling, etc., to arrive at the cost at the well.

\begin{tabular}{|c|c|}
\hline 16-in., $\frac{5}{16}$ thick (drive pipe) & $\$ 3.25$ \\
\hline $12 \frac{1}{2}$-in., $36 \mathrm{lb}$. per foot (drive pipe). & 1.20 \\
\hline 10-in., $32 \mathrm{lb}$. per foot............ & 0.85 \\
\hline $8 \frac{1}{4}$-in., 24 lb. per foot... & 0.63 \\
\hline $6 \frac{5}{8}-\mathrm{in} ., 17 \mathrm{lb}$. per foot. $\ldots \ldots \ldots \ldots \ldots \ldots \ldots \ldots$ & 0.45 \\
\hline 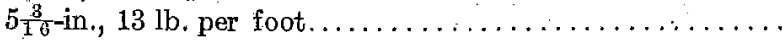 & $\therefore 0.35$ \\
\hline
\end{tabular}

Derricks.-If a well is drilled with a derrick, it is usually allowed to remain for subsequent cleaning and pulling; otherwise portable pulling machines are employed when a well needs attention. As the high drilling derricks (64 to $84 \mathrm{ft}$.) are occasionally blown over, they are often replaced by 40 -ft. pulling derricks, which are free from this danger.

Pumping Outfit.-The wells are equipped with 2 -in. pumps and tubing as the salt water is seldom so heavy as to require a 3 -in. pump. The pumps are connected to iron or wooden jacks that are operated by pull rods from a central power station driven by a 25 to $35 \mathrm{~h}$. p. gas engine: The engine and power are housed in an inexpensive corrugated-iron building and from 4 to 24 wells are pumped from one power. 
The 2-in. lead lines from the wells to the tank and the 2-in. gas lines that take off the casing-head gas aggregate 4 to 6 miles on a completely drilled 80 -acre lease ( 15 wells). They should be buried over a foot to prevent freezing in winter, or tearing open from expansion in summer, and to be safe from breakage from the farmer's plow.

Tankage.-Liberal tankage is required, compared with Eastern fields, as from 2 to 10 tanks (wood) of 250 barrels capacity are required for a 100-acre lease. A "gun-barrel," "or siphon, tank is also required for settling out the salt water, although small amounts of water, that only settles out in cold weather after thinning by steaming, are carried over into the shipping tanks. The tanks are housed in framed buildings to reduce the evaporation losses in summer.

A small boiler house located at least $100 \mathrm{yd}$. distant, 'so as not to fire the tank vapors, furnishes the steam for preparing the oil for shipping in cold weather and for operating the pipe-line pump.

Formerly the "B. S.," or the emulsion of oil, water, air, and sediment formed by improper pumping, was run off into special sludge ponds and burned, a very wasteful practice that is still quite prevalent. On the better-equipped leases the $\mathrm{B}$. $\mathrm{S}$. is treated in a sludge tank, by which considerable good oil is recovered. If the services of a capable chemist were retained practically all the B. S. could be recovered as good oil.

\section{Market Features}

Oil Prices.-Illinois is the only field that has gone through its "flush," or initial period of heavy production, and secured such high prices as 60c. to 68c. per barrel. Other fields have had to accept 3c. to 30c. during the inevitable heart-breaking interim that intervenes between overflowing field-tanks and the subsequent bringing in of sufficient pipe lines. This great advantage is due to its proximity to St: Louis and Chicago, where the oil would have found a welcome market at $40 \mathrm{c}$. to $50 \mathrm{c}$. in competition with coal.

When shipments began in June, 1905 , the oil sold at 60c. and advanced to $83 \mathrm{c}$. by June, 1906; after which it declined, remaining at 68c. throughout 1908 and again reached the low point of 60c. in October, 1909, where it remained until May, 1911. Since then, the price has continuously advanced and to-day, Jan. 29,1914 , it is selling at $\$ 1.45$ in the open market, as paid by the Ohio Oil Co. (branch of the Standard Oil Co.). Independent buyers pay a premium of 5c. to $20 \mathrm{c}$. a barrel, as on equal terms most producers prefer to sell to the Standard Oil Co., and it is only by giving a premium that they are able to divert it from the principal buyer. Formerly there was a discount of 8c. per barrel for oil below $30^{\circ} \mathrm{B}$. gravity, but for the past year all grades have sold at the same price. 
The oil is purchased in the producer's tanks after gauging and run off through the buyer's pipe line, with an extra allowance of 1c. to $2 \mathrm{c}$. per barrel for the steam furnished to operate the buyer's pump that forces the oil into the pipe line. A dockage of 3 per cent. is usually made to allow for losses due to salt water, B. S., evaporation, leakage, etc. A "credit balance" ticket is made out by the buyer three days after the oil is shipped for the net barrels due the operator after deducting royalty and dockage. This ticket can be cashed at the market price for oil ruling that day, or it can be held to be cashed later, if higher prices are expected. Before the oil markets were stabilized by the present powerful interests, there were most violent fluctuations in oil prices that outrivaled Wall Street stocks, and operators who had the working capital held their tickets for the winter market, when prices generally ruled higher.

The unprecedented prosperity of the oil industry, the enormous increase in the demand for high-grade oils (paraffine base) to meet the rapidly expanding uses of gasoline and lubricants, and the almost complete exhaustion of the Illinois surplus stocks assure much higher prices for Illinois oil in the not distant future.

Storage.-As the Illinois oil is of too high a grade to be sacrificed for fuel, the large buyers built steel tankage to take care of the surplus oil before there were sufficient pipe lines. About 1,000 tanks of 35,000 barrels capacity were erected throughout the field, which contained about $33,000,000$ barrels of oil in 1910. As the demand for Illinois oil has been much greater than the supply for the past three years, this surplus has been heavily drawn on to meet the deficit and to-day there remains about $5,500,000$ barrels.

Pipe Lines.-No oil field has been as well taken care of in being promptly and completely equipped with pipe lines as Illinois. The magnitude of the field, the richness of the wells, and the high grade of the oil caused the pipe-line companies to go to enormous outlays to run the oil from the tanks of any and every producer and their total daily shipping capacity now exceeds 140,000 barrels.

The Ohio Oil Co. controls most of the lines, having a complete series of gathering lines throughout all the districts in eastern and western Illinois. It has an 8-in. line across the State to the Wood River refinery, 140 miles; two 8-in. lines to the Lima trunk line, 200 miles; and a 12-in. line to New York harbor, 900 miles. There is a pumping station at Bridgeport, in the Southern district, with 60,000 barrels capacity, that pumps the oil at $800 \mathrm{lb}$. pressure to Stoy, 25 miles, in the Central district. Another station at Stoy pumps the oil to Martinsville, 25 miles, in the Northern district, where all the oil from the Eastern field concentrates. From there it is distributed through the Eastern and Western pipe lines. 
The Tidewater Co. has a 6-in. pipe line to the Atlantic seaboard and gathering lines throughout Crawford and Lawrence counties.

The Indian Refining Co. has gathering lines in Lawrence county, as also the Central and Sun companies, which run to their refineries' at Lawrenceville.

The Leader Pipe Line Co. has gathering lines in Clark county for its refinery at Casey, from which the surplus oil is shipped to Pennsylvania refiners by tank cars. The Robinson refinery has gathering lines in Crawford county.

Railroads. - The five railroads that tap the Eastern Illinois field moved large quantities of oil before the pipe lines were completed and they still transport considerable oil for the smaller refineries from loading racks distributed throughout the field. While most of the refiners own their own tank cars, tank-car companies rent out hundreds of cars to the smaller shippers, at usually $\$ 1$ per day.

The Western field is well equipped with railroads, which have thus far handled most of the oil.

Refineries.-Although most of the Illinois crude oil is piped to the large refineries on the Atlantic seaboard, there are nine refineries in Illinois that rely on the local output, of which six are on the eastern and three on the western side of the State.

At Lawrenceville is the large Indian 'refinery, of 9,000 barrels daily capacity, that makes a full line of products (gasoline, kerosene, lubricants, paraffine; etc.); the Central, with a capacity of 3,000 barrels, that co-operates with an asphalt plant, and the Sun Co. operates a 400-barrel skimming plant that makes gasoline and fuel oil.

There is a 600-barrel refinery at Robinson, a 600-barrel refinery at Casey, and a refinery at Chicago, the latter relying on tank-car shipments.

In western Illinois there are two refineries at East St. Louis that depend on tank-car shipments and a large refinery at Wood River, 20 miles from St. Louis, of 10,000 barrels capacity, owned by the Indiana Standard Oil Co.

\section{Production Prices}

The value of production and of operating leases has greatly increased as oil prices have advanced, and developed properties are almost unpurchasable. When oil was selling at $60 \mathrm{c}$. production sold at $\$ 300$ to $\$ 400$ per barrel of daily output. When oil reached $\$ 1$ it advanced to $\$ 800$ to $\$ 1,000$. At present, with oil at $\$ 1.45$ to $\$ 1.65$, production is held at $\$ 1,250$ to $\$ 1,500$ per barrel, according to the age and size of the wells, locations undrilled, royalty, condition of plant, equipment, and other modifying operating details. These prices are based on "settled" production, or after the flush period, or when the wells are about a year old. 
Pennsylvania production, where the oil is higher grade, or $40^{\circ}$ to $46^{\circ}$ gravity, and sells for $\$ 2.50$ a barrel, is rated at $\$ 2,000$ to $\$ 3,000$ per barrel, although the wells yield only $\frac{1}{5}$ to $\frac{1}{2}$ barrel a day, and, like Illinois, it is almost impossible to induce a producer to sell at any price.

At these prices, the investment is expected to be returned in 1,000 to 1,200 days.

\section{Royalties and Rentals}

Eastern Field.-When the Eastern field was opened, the royalty was one-eighth of the production; or the customary rate in the older fields. When the field proved so rich, the competition among the oil men for leases resulted in the royalty advancing to one-sixth to one-fourth, and even three-eighths to one-half in extreme cases. The royalty on gas wells similarly increased from $\$ 50$ to $\$ 100$ per well annually to $\$ 150$ to $\$ 200$.

The rental to hold a lease good until a well is drilled was formerly $25 \mathrm{c}$. to $\$ 1$ per acre annually, but lately $\$ 1$ to $\$ 4$ per acre is demanded, and then only 1 to 2 years allowed, compared with 5 to 10 years in the earlier leases.

Western Illinois.-In western Illinois the royalties and rentals are still reasonable, or one-eighth on the oil and $\$ 50$ to $\$ 100$ a year per gas well, while the leases can usually be carried 5 to 10 years without drilling on paying an annual rental of $50 \mathrm{c}$. to $\$ 1$ per acre.

\section{Cost of Oil Leases}

The bonus, or cash price, paid to obtain an undeveloped lease varies greatly according to the distance from production, richness of the discovery well, and terms of the lease. Leases favorably situated on anticlines in an undeveloped territory go begging at a few dollars per acre until a discovery is made in the vicinity, when they quickly advance to $\$ 25$ to $\$ 50$ an acre if not over 5 miles distant, and to $\$ 100$ to $\$ 350$ an acre if within 2 miles. The discovery of a new pool promptly brings out hundreds of active, keen buyers from the old oil fields, who purchase at rapidly advancing prices every available lease for 7 to 15 miles in every direction. Leases 10 miles distant will bring $\$ 5$ to $\$ 15$ an acre from late comers af ter the nearer leases have been secured by the excited buyers. Within 30 days several million dollars will be invested in leases, of which 60 to 70 per cent. will probably prove unproductive. Yet pool after pool in Illinois (and elsewhere) has been the scene of repeated large investments in undeveloped oil leases around a discovery well by a horde of feverish buyers. While many speculators rush in to every new discovery, most of the buyers are old, seasoned oil operators who can no more resist the faseination of a "wild-cat" well that has made good than a tenderfoot can escape the lure of a mining boom in a gold camp. 


\section{Operating Expenses}

The field expenses for producing oil in Illinois, including labor and upkeep, vary greatly according to size and conditions of the lease, the size of the wells, and amount of salt water. Excessive salt water requires the wells to be pumped by night as well as on the day shift and Sundays, whereas with little or no salt water day pumping suffices. As a pumper is generally required to every lease, whether it contains 40 or 160 acres, it makes the labor cost per barrel excessively heavy on the small leases, especially if operated double-shift.- Similarly, if the wells are small, the labor costs per barrel are heavy compared with large wells.

The extra labor required for cleaning the wells, repacking, etc., will vary according to the condition of the wells, as old wells that have not been over-shot may have to be pulled only once or twice a year, whereas sand troubles caused by over-shooting may constantly require a pulling crew. The pumpers are paid $\$ 65$ to $\$ 75$ a month and live on the lease in a small cottage provided by the operators.

When an operator has several leases in a district a "farm boss" is employed, who keeps a crew of two to four "rousters" steadily employed in looking after the wells. The rousters are paid $\$ 60$ to $\$ 70$ a month and a farm boss from $\$ 100$ to $\$ 115$.

The usual field expense of putting the oil into the tanks ready for the buyer will range from 3c. to $7 \mathrm{c}$. a barrel on leases of 80 to 160 acres, with large wells, or over 20 barrels per day; with smaller leases, or 20 to 80 acres, or where the wells yield 5 to 15 barrels, the cost will range from $7 \mathrm{c}$. to $15 \mathrm{c}$; ; with very small wells, or 2 to 5 barrels, the cost increases to 15c. to 30c. per barrel.

When the leases are very small and in town-lot production, one pumper is usually put in charge of several leases and thus the labor cost is brought down to a reasonable amount.

\section{Operating Profits}

The net operating profits from Illinois oil production vary greatly according to the size of the wells, their staying power, depth and number of sands, size and age of lease, royalty, oil market, and other local conditions, besides depending on the capital invested for leases, drilling, plant, etc., and the individual operating costs.

The Illinois oil wells usually repay their cost in 30 to 90 days when not over $1,100 \mathrm{ft}$. deep and in 60 to 180 days in the deep sands, or 1,200 to $1,900 \mathrm{ft}$. Occasional large wells repay their cost in 5 to 20 days, while very small wells may take a year.

The capital for the acquisition, development, and equipment of an undeveloped property in a proven field is usually returned in the first year and will show the following great range: The lease will cost from $\$ 25$ 
to $\$ 300$ an acre, according to the distance from and richness of the discovery well; the wells will cost $\$ 1,000$ to $\$ 8,000$ each, according to depth; the plant investment for power, rodding, piping, tankage, boilers, buildings, etc., will range from $\$ 2,000$ to $\$ 10,000$, according to the size of the lease and local conditions. Yet many Illinois leases have returned the total capital invested in 4 to 16 months, when oil sold at $60 \mathrm{c}$. to $80 \mathrm{c}$. a barrel.

The net operating profits at present prices of oil $(\$ 1.45$ to $\$ 1.60)$, after deducting the royalty and operating expenses, usually range from $\$ 1$ to $\$ 1.30$ a barrel. Small leases (5 to 20 acres), town-lot wells, very small wells ( 1 to 3 barrels), or excessive royalties (three-eighths to onehalf), may reduce the net profit per barrel to $50 \mathrm{c}$. to $80 \mathrm{c}$.

A fair example of oporating profits is shown in the following 120acre lease in the shallow Casey field, where the wells came in at 10 to 50 barrels, seldom at 100 barrels per day, and the oil sold for 60c. to $82 \mathrm{c}$. a barrel: The oil royalty was one-eighth, the cost of the lease was $\$ 100$ an acre, and the wells cost about $\$ 1,000$ complete, as they were in the $400-\mathrm{ft}$. sand. In the first year the investment of $\$ 43,000$ was returned; in the following 54 months, when the property was sold, the profits ranged from 6 to 40 per cent. per month.

\section{Gas Developments}

Paucity Due to Leakage.--Although Illinois has proved an exceptionally rich oil producer, the gas output is disappointing, While sufficient gas is usually produced to operate with and supply the neighboring towns, not enough has been developed to warrant piping to the metropolitan markets of St. Louis and Chicago.

This paucity seems to be due to faulting, as minor faults occur that apparently have allowed more or less of the gas to escape. That the gas has been only partly preserved is shown not only by the small size of the wells, but usually by the absence of the heavy pressures that occur in other fields.

That faulting is responsible for the deficiency is verified at Centralia, where there is no gas; yet 6 miles north, at Sandoval, on the same anticline, the same sands are rich in gas; but at Centralia a fault is shown by the coal mines that has not only vented the gas, but is permitting some of the viscous oil to escape into the coal shafts.

The northern parts of the fields usually have more gas than the southern portions, which harmonizes with the faulting theory, as the faults are more numerous and heavier toward the south, from the closer proximity to the Ozark uplift.

That the oil has been so slightly affected by the faults-at least, in the lower sands-is due to its viscous nature and strong capillary adhesion as compared with the great elasticity and extreme mobility of the gas. 
For the gas can move and more or less escape through minute fractures caused by faulting that are more or less impervious to the viscous oil.

Gushers.--On the opening of a new pool the gas pressure is often sufficient to cause the wells to flow intermittently for a short time, or until the pressure is relieved. The gusher type is exceptional, however, and most wells have to be pumped from the outsèt.

Size of Gas Wells.-Gas wells usually come in at 200,000 to 1,000,000 cu. ft. a day, rarely at 2,000,000 to 5,000,000, which for a new field is modest. There are comparatively few "dry" gas wells, as the gas generally occurs with the oil; hence when a "gasser" is found the oil usually occurs in the immediate vicinity.

Values.-The towns are supplied by local gas companies at $20 \mathrm{c}$. to 30c. per $1,000 \mathrm{cu}$. ft. for domestic purposes and the gas is metered. The companies either have their own wells, or buy gas from oil producers, who have an excess, at $5 \mathrm{c}$. to $10 \mathrm{c}$. per 1,000 cu. ft.- at the wells. .

Drillers are furnished gas at a flat rate of $\$ 5$ á day for the boiler and lighting.

The value of the Mlinois gas output in 1912 is estimated ${ }^{6}$ at $\$ 616,467$, or about 2 per cent. of the oil value, of which $1,236,162,000 \mathrm{cu}$. $\mathrm{ft}$. was sold at an average of $23.62 \mathrm{c}$. for domestic use and $5,603,318,000 \mathrm{ft}$. at $7.43 \mathrm{c}$. for industrial purposes.

The actual production was much larger, as the oil operators continue to waste large quantities, especially in new pools and when a flowing well comes in.

\section{Gasoline from $\bar{G}$ as}

Few Plants.-The Illinois oil field is so young and so lucrative that thus far little attention has been paid to gas gasoline. The old wells of Pennsylvania are so small and the casing-head gas is usually so rich that the gas-gasoline revenue of ten exceeds that from the oil, whereas in Illinois it amounts to only 5 to 10 per cent. of the oil revenue. As the Illinois wells decline and as the gas grows richer, more attention will be given to extracting the gasoline. Only six plants are operating in eastern Illinois and compound compressors are employed to liquefy the gasoline vapors that are contained in the gas. Two grades are made, or a high-grade $70^{\circ}$ to $80^{\circ}$ gravity gasoline by the low-pressure cylinder and a very highgrade $80^{\circ}$ to $95^{\circ} \mathrm{B}$. fluid by the high-pressure cylinder. Both grades are usually blended with naphtha, to render them safe for shipping and to reduce the heavy volatilization loss. The $90^{\circ}$ to $95^{\circ}$ gravity fluid is so extremely volatile that if a cupful is tossed into the air on a warm day, it will volatilize before reaching the ground.

Yield.-The gasoline yield of Illinois gas ranges from 1.5 to $2.5 \mathrm{gal}$.

${ }^{6}$ Production of Natural Gas in 1912, U. S. Geological Survey, p. 5 (1913).

YoL. XLVIII.-36 
per $1,000 \mathrm{cu}$. $\mathrm{ft}$., and about 75 per cent. of the gas is available for returning to the gas main, if subsequently utilized,

Prices.-The gasoline is frequently retailed from the lease to automobiles at 12c. to $15 \mathrm{c}$. a gallon, although large producers usually sell it to jobbers at $8 \mathrm{c}$. to $10 \mathrm{c}$. It has to be shipped in steel containers, as the loss and risk are too great to permit shipment in wooden barrels.

There is a keen demand for this exceptionally high-grade gasoline and the industry has a bright future that the Illinois operators should more generally appreciate.

\section{Statistics}

The data given in the following statistics were obtained from the annual Mineral Statistics, published by the U. S. Geological Survey, or from the Oit City Derrick.

Table II presents a summary of the wells drilled to Jan. 1, 1914, in Illinois, since the marked activity started in 1906 . It shows a tremendous outburst of activity in 1907, when about 5,000 holes were drilled, since which there has been a steady, marked decline until 1913 . The high prices for oil stimulated the drilling of many inside locations last year, where the sands had been more or less drained, which accounts for the smaller percentage of dry holes and the much lower average yield.

The average yield declined from 40.4 barrels in 1906 to 26.1 barrels in 1908, as the flush period passed in the very active shallow Crawford County district. The greater activity in the deeper but richer sands of Lawrence county reversed the usual retrogression that nearly all young fields exhibit and the average output of the now wells steadily increased up to 1912, when it averaged 67 barrels per well, which is exceptionally high for a high-grade field.

TABLE II.-Summary of Illinois Drilling

\begin{tabular}{|c|c|c|c|c|c|c|c|c|c|}
\hline \multirow{3}{*}{ Year } & \multirow{3}{*}{$\begin{array}{c}\text { Wells } \\
\text { Drilled }\end{array}$} & \multicolumn{2}{|c|}{ Produced Oil } & \multirow{2}{*}{\multicolumn{2}{|c|}{$\begin{array}{l}\text { Initial Yield } \\
\text { Barrels }\end{array}$}} & \multicolumn{2}{|c|}{ Produced Gas } & \multicolumn{2}{|c|}{ Dry } \\
\hline & & \multirow[b]{2}{*}{ Number } & \multirow[b]{2}{*}{$\begin{array}{l}\text { Per } \\
\text { Cent. }\end{array}$} & & & \multirow[b]{2}{*}{$\begin{array}{c}\text { Num- } \\
\text { ber }\end{array}$} & \multirow[b]{2}{*}{$\begin{array}{l}\text { Per } \\
\text { Cent. }\end{array}$} & \multirow[b]{2}{*}{$\begin{array}{c}\text { Num- } \\
\text { ber }\end{array}$} & \multirow[b]{2}{*}{$\begin{array}{l}\text { Per } \\
\text { Cent. }\end{array}$} \\
\hline & & & & $\begin{array}{l}\text { Total } \\
\text { Yield }\end{array}$ & $\begin{array}{l}\text { Daily } \\
\text { Yield }\end{array}$ & & & & \\
\hline 1905 & 227 & 189 & 83.2 & & & . & & 37 & 16.8 \\
\hline 1906 & 3,283 & 2,793 & 85.1 & 113,012 & 40.4 & . & $\ldots$ & 490 & 14.9 \\
\hline 1907 & 4,988 & 4,260 & 85.4 & 139,163 & 32.6 & $\ldots$ & $\ldots$ & 728 & 14.6 \\
\hline 1908 & 3,574 & 3,019 & 84.5 & 78,960 & 26.1 & $\ldots$ & $\ldots$ & 555 & 15.5 \\
\hline 1909 & 3,151 & 2,593 & 82.3 & 89,756 & $34: 0$ & 70 & 2.2 & 485 & 15.4 \\
\hline 1910 & 2,149 & 1,681 & 78.2 & 93,256 & 55.8 & 75 & $3: 4$ & 393 & 18.3 \\
\hline 1911 & 1,365 & $1 ; 061$ & 77.7 & 66,919 & 63.1 & 42 & $3: 1$ & 263 & 19.2 \\
\hline 1912 & 1,260 & 980 & 77.8 & 65,686 & 66.6 & 23 & 1.8 & 257 & 20.4 \\
\hline 1913 & $1 ; 747$ & 1,439 & 82.0 & 47,558 & 33.3 & 40 & 2.4 & 268 & 15.6 \\
\hline Totals & 21,744 & 18,025 & 82.9 & 694,310 & 38.5 & & & $3 ; 486$ & 16.0 \\
\hline
\end{tabular}


Table III gives the average initial daily yield of the wells in the producing counties of Illinois and gives an approximate idea of the relative richness of the sands. It also shows the activity in drilling inside wells in 1913 in all the counties, and the consequent drop-off in the yield.

\section{TẢble III.-Average Initial Daily Yield of Illinois Wells by Counties}

\section{Eastern Field.-Barrels}

\begin{tabular}{|c|c|c|c|c|c|c|c|}
\hline County & 1907 & 1908 & 1909 & 1910 & 1911 & 1912 & 1913 \\
\hline Clark. & 20.9 & 23.3 & 24.0 & 22.5 & 17.1 & 23.6 & 15 . \\
\hline Coles. & 7.0 & 15.3 & 10.6 & 16.3 & 5.0 & 5.0 & 20 \\
\hline$\ldots \ldots \ldots \ldots 66.1$ & 34.2 & 23.5 & 25.5 & 27.8 & 26.6 & 23.1 & 17.1 \\
\hline Cumberland $\ldots \ldots \ldots \ldots \ldots 29.9$ & 26.0 & 9.8 & 24.3 & 12.5 & 16.7 & 19.0 & 12.0 \\
\hline Edgar........... & 10.7 & 6.4 & 5.0 & & $\ldots$ & $\cdots$ & \\
\hline Lawrence. & 49.2 & 36.2 & 61.5 & 102.7 & 86.8 & 10.5 & 54.0 \\
\hline Jasper... & $\ldots$ & $\ldots$ & 7.1 & 10.0 & 6.7 & $\ldots$ & \\
\hline$\therefore \ldots \ldots \ldots \ldots \ldots$ & Fielo & -Barrel & $\ldots$ & . & $\ldots$ & 50.0 & 39 \\
\hline Bond. & . & $\ldots$ & $\cdots$ & 25.0 & .. & & \\
\hline$\ldots \ldots \ldots \ldots \ldots$ & . & - & $\ldots$ & $\cdots$ & 95.0 & 32.2 & 10 \\
\hline $\mathrm{Ma}$ & . & . & 5.0 & & 3.5 & 3.0 & 55 \\
\hline Marion... & & . & 37.2 & 110.6 & 91.5 & 27.7 & 23 \\
\hline Randolph. & & & 72.5 & & - & $\cdots$ & \\
\hline . & & 6.2 & 4.6 & & 63.0 & 67.0 & \\
\hline
\end{tabular}

\section{TABLE IV:-Wells Drilled in Illinois in 1913}

\begin{tabular}{|c|c|c|c|c|}
\hline County & $\begin{array}{l}\text { Wells } \\
\text { Drilled }\end{array}$ & $\begin{array}{l}\text { Produced } \\
\text { Oil } \\
\text { Per Cent. }\end{array}$ & $\begin{array}{c}\text { Average Initial } \\
\text { Daily Output } \\
\text { Barrels }\end{array}$ & $\begin{array}{c}\text { Dry } \\
\text { Holes } \\
\text { Per Cent }\end{array}$ \\
\hline & 208 & 81 & 15.2 & 19 \\
\hline 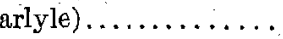 & 19 & 74 & $10: 0$ & 26 \\
\hline & 6 & 67 & 20.0 & 33 \\
\hline obinson) ......... & 689 & 80 & 17.1 & 20 \\
\hline (Siggins) . ........ & 63 & 80 & 12.0 & 20 \\
\hline Bridgeport) ........ & 667 & 89 & 54.0 & 11 \\
\hline Carlinville) ........ & 9 & 33 & 55.0 & 67 \\
\hline$\ldots \ldots \ldots$ & 22 & 95 & 23.0 & 5 \\
\hline ndale $). . \ldots \ldots \ldots$ & 49 & 50 & 39.0 & 50 \\
\hline$\ldots \ldots \ldots \ldots \ldots$ & 15 & 13 & 12.0 & 87 \\
\hline ‥ & 1,747 & $\overline{82}$ & 33.3 & 18 \\
\hline
\end{tabular}

Clark (Casey) ........... 208

Coles.................... 6

Crawford (Robinson) ........ 689

Cumberland (Siggins) ........ 63

Lawrence (Bridgeport) ........ 667

Macoupin (Carlinville) ......... 9

Marion (Sandoval) .......... 22

Wabash (Allendale).......... . 49

Miscellaneous.............. 15

Total

1,439 wells $=82.0$ per cent. came in with an ouput of 33.3 barrels daily (average),

40 wells $=2.4$ per cent. came in as gas wells.

268 wells $=15,6$ per cent, came in as dry holes.

1,747 wells $=100.0$ per cent. or the total wells completed in 1913.

Table IV shows that 1,747 wells were drilled in Illinois in 1913, of which 82 per cent. were oil producers that came in at an average of 33.3 
barrels per day, and 2.4 per cent. were gas producers. It also shows that almost no prospecting was carried on, as onily 15 holes were drilled outside of the producing fields. This insignificant effort to open up new territory was largely due to the great scarcity of drillers, who were attracted by the ferce boom in Oklahoma, where rates are higher and work was very plentiful.

Table V presents a summary of the drilling in 1913 in the States that exclusively produce high-grade oil (paraffine base). It shows their relative activity by the number of wells completed; and while the drill was unusually busy in all, it shows the extent of the unprecedented boom in Oklahoma, where over 9,000 holes were drilled. In spite of bringing in the very rich Cushing and Boston pools in Oklahoma, the average well shows a further decline to 46 barrels per day, although in the old nip-and-tuck race with Illinois for first honors in the highest average well, it leads the latter (33.3 barrels) by nearly as large a margin as Illinois with 67 barrels led Oklahoma in 1912 , at 48.6 barrels.

With the exception of New York (where the average well came in at 1.8 barrels, which would be called a dry hole in Illinois), the record of 82 per cent. of the Illinois wells coming in as oil producers is the highest, as the other States range from 80 to 38 per cent.

TaBLe V.-Wells Drilled in the High-Grade Oit Fields in 1913

\begin{tabular}{|c|c|c|c|c|c|c|c|c|c|}
\hline \multirow[b]{2}{*}{ State } & \multirow{2}{*}{$\begin{array}{c}\text { Wells } \\
\text { Drilled }\end{array}$} & \multicolumn{2}{|c|}{ Produced Oil } & \multicolumn{2}{|c|}{$\begin{array}{c}\text { Initial Yield } \\
\text { Barrels }\end{array}$} & \multicolumn{2}{|c|}{$\begin{array}{l}\text { Produced } \\
\text { Gas }\end{array}$} & \multicolumn{2}{|c|}{ Dry } \\
\hline & & $\begin{array}{l}\text { Num- } \\
\text { ber }\end{array}$ & $\begin{array}{c}\text { Per } \\
\text { Cent. }\end{array}$ & Tọtal & $\begin{array}{l}\text { Daily } \\
\text { Aver- } \\
\text { lage }\end{array}$ & $\begin{array}{c}\text { Num- } \\
\text { ber }\end{array}$ & $\begin{array}{l}\text { Per } \\
\text { Cent. }\end{array}$ & $\begin{array}{l}\text { Num- } \\
\text { ber }\end{array}$ & $\begin{array}{c}\text { Per } \\
\text { Cent. }\end{array}$ \\
\hline Jew Yo & 510 & 44 & 87 & 807 & 1.8 & 45. & 9.0 & 22 & 4. \\
\hline Pennsylvania. & 3,719 & 2,961 & 80 & 8,155 & 2.8 & 263 & 7.0 & 495 & 13.0 \\
\hline West Virginia. & 2,072 & 1,290 & 62 & 34,287 & 26.6 & 453 & 22.0 & 329 . & 16.0 \\
\hline Ohio. . & 1,447 & 551 & 38 & 13,409 & 24.3 & 685 & $47: 0$ & 211 & 15. \\
\hline Indiana. & 310 & 212 . & 68 & 7,361 & 34.7 & 12 & 4.0 & 86 & 28. \\
\hline Kentuck & 211 & 134 & 64 & 2,310 & 17.0 & 3 & 1.5 & 74 & 34. \\
\hline Mlinois & 1,747 & 1,439 & 82 & 47,558 & 33.3 & 40 & 2.4 & 268 & 15. \\
\hline Kanse & 2,149 & 1,583 & 73 & 22,985 & 14.5 & 292 & 14.0 & 274 & 13. \\
\hline Oklahoma.. & 9,112 & 7,232 & 79 & 331,385 & 46.0 & 572 & 6.0 & 1,306 & 15.0 \\
\hline
\end{tabular}

The richness of the Illinois fields is shown in Table V, as its high daily average production of 33.3 barrels exceeds all the other States (1.8 to 24.3 barrels) excepting Oklahoma, as previously mentioned, and Indiana (34.7 barrels); the latter State made an unprecedented record, as its wells usually come in at 10 to 20 barrels. The increase is due to the opening up of the new Sullivan County field, which adjoins Crawford county, Ill., and seems to be influenced by the same cross-anticlinal zone that passes through the latter. 